\title{
TUNAS
}

JURNAL PENDIDIKAN GURU SEKOLAH DASAR

http://journal.umpalangkaraya.ac.id/index.php/tunas

Volume 7 Nomor 1, Desember 2021 (32-37)

\section{DAMPAK PEMBELAJARAN KURIKULUM 2013 PADA MASA PANDEMI COVID-19}

The Impact Of The 2013 Curriculum Learning On The Pandemic Covid-19

Fitri Indra Wati

Pascasarjana Universitas Lambung Mangkurat Banjarmasin, Kalimantan Selatan, Indonesia.

\section{ARTIKEL INFO}

Diterima

November 2021

Dipublikasi

Desember 2021 *e-mail :

fitriindrawati65@gmail.c om

\section{ABSTRAK}

Dampak pada pendidikan saat pandemi mengakibatkan pemerintah menutup sementara semua sekolah, di seluruh negara termasuk Indonesia. Walaupun sekolahsekolah tutup, hal tersebut membawa dampak perubahan sosial ekonomi yang besar. UNESCO telah merekomendasikan program pembelajaran jarak jauh menggunakan zoom atau platform pendidikan online lainnya, sehingga guru dan sekolah dapat menjangkau siswa dan gangguan pendidikan dapat dikurangi selama penutupan sekolah yang disebabkan karena COVID -19. Untuk itu tujuan dari penelitian ini adalah untuk mengidentifikasi informasi mengenai dampak dari pandemi COVID-19 terhadap proses pembelajaran dan pelaksanaan kurikulum 2013.

Penelitian ini menggunakan metode descriptive content analysis study dan studi literatur yang merupakan sebuah analisis yang bertujuan untuk mendeskripsikan atau menganalisis masalah pokok berdasarkan kumpulan informasi yang diperoleh. Informasi bisa bersumber dari berbagai artikel ilmiah yang berkaitan dengan pelaksanaan pembelajaran daring selama pandemi COVID-19. Dikarenakan sekarang masih dalam masa pandemi COVID-19 maka dalam pendidikan kurikulum 2013 diterapkan sesederhana mungkin agar pendidikan di Indonesia masih bisa terlaksana dalam penerapan pembelajarannya.

Sistem pembelajaran daring dengan memanfaatkan platform digital mengubah wajah pendidikan di Indonesia ke arah yang lebih baik, lebih efektif, dan lebih menyenangkan dalam dampak postifnya, tetapi ada dampak negatif juga, Walaupun demikian perlu dilakukan penyesuaian kembali dengan beragam kemampuan masingmasing pada guru, siswa, dan orang tua siswa dalam memberikan fasilitas pembelajaran daring, sehingga kendala yang dialami dapat diminimalisir. Kata Kunci : Dampak Pembelajaran, Kurikulum 2013, COVID-I9.

\section{ABSTRACT}

The impact on education during the pandemic resulted in the government temporarily closing all schools, in all countries including Indonesia. Even though schools were closed, this had a major socio-economic impact. UNESCO has recommended distance learning programs using zoom or other online education platforms, so that teachers and schools can reach students and educational disruptions can be reduced during school closures caused by COVID-19. For this reason, the purpose of this study was to identify information regarding the impact of the COVID-19 pandemic on the learning process and implementation of the 2013 curriculum.

This research uses descriptive content analysis study and literature study, which is an analysis that aims to describe or analyze the main problem based on the collection of information obtained. Information can be sourced from various scientific articles related to the implementation of online learning during the COVID-19 pandemic. Due to the current COVID-19 pandemic, the 2013 curriculum is implemented as simply as possible so that education in Indonesia can still be implemented in the application of learning.

The online learning system by utilizing digital platforms changes the face of education in Indonesia to be better, more effective, and more enjoyable in its positive impact, but there are also negative impacts. , and parents in providing online learning facilities, so that the obstacles experienced can be minimized. Keywords: Learning Impact, Curriculum 2013, COVID-19. 
Jurnal Pendidikan Guru Sekolah Dasar PENDAHULUAN

Saat ini dunia tengah di kejutkan dengan wabah COVID-19 (Corona Virus Desease) yang di kabarkan berasal dari kota wuhan, cina sejak desember 2019 (Lee, 2020). WHO menyatakan wabah ini sebagai pandemi global karena penularan virus ini sangatlah cepat dan sebagian besar negara di dunia turut terpapar virus ini termasuk juga Indonesia yang mengakibatkan terdampak pada ranah pendidikan. Pemeritah Indonesia telah menutup sementara semua sekolah, di seluruh negara tidak terkecuali Indonesia, walaupun sekolah-sekolah di tutup sementara bahkan saat itu membawa dampak pada perekonomian. UNESCO telah merekomendasikan program pembelajaran jarak jauh dan platform pend idikan online lainnya agar guru dan sekolah bisa menjangkau siswa dan gangguan pendidikan dapat dikurangi selama penutupan sekolah yang disebabkan karena COVID - 19.

Dalam institusi pendidikan di Indonesia, kurikulum yang diterapkan pada pendidikan dasar dan menengah adalah kurikulum 2013. Menurut Daryanto (20l4) bahwa tema pembaharuan dan perbaikan pada kurikulum 2013 yaitu ingin menciptakan manusia Indonesia yang mampu berpikir kreatif, produktif, inovatif, proaktif, dan afektif, melalui pengembangan sikap (tahu mengapa), keterampilan (tahu bagaimana), dan pengetahuan (tahu tentang apa) secara integrative, kebijakan pemerintah Indonesia dalam menyikapi wabah ini adalah dengan memberlakukan prinsip social distancing pada seluruh lapisan masyarakat, bahkan di beberapa kota besar di Indonesia di berlakukan juga kebijakan pemerintah guna mencegah penyebaran virus yaitu PSBB (Pembatasan Sosial Berskala Besar) tujuanya untuk memutus rantai penyebaran virus ini. Namun kebijakan tersebut memberikan dampak pada pendidikan di Indonesia khususnya pada proses pembelajaran bagi siswa sekolah, saat pandemi berlangsung, kini pembelajaran daring telah dilakukan di hampir seluruh dunia (Goldschmidt, 2020). Di saat pembelajaran daring ini, semua elemen termasuk pendidikan untuk tetap mampu memfasilitasi pembelajaran agar tetap aktif meskipun tanpa tatap muka secara langsung. Dalam penelitian ini akan membahas dampak dari pandemi COVID-19 terhadap proses pembelajaran di sekolah pada kurikulum 20I3.

\section{METODOLOGI PENELITIAN}

Untuk penelitian ini menggunakan metode descriptive content analysis study yaitu studi literatur yang merupakan sebuah analisis yang bertujuan untuk mendeskripsikan masalah pokok berdasarkan kumpulan informasi yang diperoleh dalam informasi yang dimaksud bersumber dari berbagai artikel ilmiah yang berkaitan dengan pelaksanaan pembelajaran daring selama pandemi COVID19. Artikel-artikel ilmiah yang dimaksud adalah artikel yang didapat dari jurnal nasional serta Jurnal Internasional. Jurnal-jurnal tersebut dijadikan sumber daya dan referensi yang relevan dan informasi yang telah diperoleh selanjutnya dikumpulkan, dianalisis, dan disimpulkan sehingga mendapatkan rekomendasi sebagai studi literatur.

\section{HASIL PENELITIAN DAN PEMBAHASAN}

Surat edaran menteri pendidikan dan kebudayaan republik Indonesia Nomor 4 Tahun 2020 tentang pelaksanaan kebijakan pendidikan dalam masa darurat penyebaran Corona virus Diseas (COVID-19). Surat tersebut memuat secara keseluruhan protokol dan teknis yang harus diterapkan oleh sekolah dalam menyelenggarakan proses pendidikan. Surat tersebut memberi pedoman secara umum tentang pelaksanaan Pembelajaran Jarak Jauh (PJJ) yang penting bagi keberlanjutan proses pendidikan yang sempat terhenti selama beberapa saat akibat Pandemi COVID-19. Pedoman yang diberikan oleh pemerintah ini menjadi landasan yang utama penerapan teknologi dalam proses 
Jurnal Pendidikan Guru Sekolah Dasar pembelajaran, tidak dapat di pungkiri bahwa pembelajaran jarak jauh di masa pandemi ini memiliki dampak dalam pendidikan.

Menurut Destri (2020) dalam dampak belajar di rumah juga dirasakan oleh orang tua yang mereka terlebih dahulu memiliki beban lebih karena harus menjadi guru di rumah, mengajar membuat tugas, dan selalu memantau. Bisa di bayangkan jika anak lebih dari satu dan masih membutuhkan bantuan dalam melakukan tugas, juga belum lagi harus menyiapkan makanan dan pekerjaan rumah tangga lainnya. Sehingga sukacita dan kesedihan selama proses belajar di rumah beragam, kadang beberapa orang tua lebih suka anak-anak belajar di sekolah. Selain biaya internet yang membengkak, salah satu keluhan orang tua adalah peningkatan pengeluaran untuk konsumsi yang lebih besar daripada tunjangan anak setiap hari. Sehingga maka nilai positifnya adalah bahwa ada lebih banyak waktu untuk berkumpul dengan keluarga dan untuk mendekatkan hubungan emosional antara orang tua dan anak- anak dan yang lebih penting adalah keluarga lebih terlindungi dari paparan virus korona. Menurut Purwanto,dkk. (2020) dengan tinggal di rumah untuk memutus rantai penyebaran virus memang merupakan solusi yang tepat. Sehingga hal ini tidak terlepas dari masalah yang akan terjadi di masa depan, seperti tidak mampu untuk melakukan berbagai kegiatan normal pada umumnya tetapi di tempat kerja. Menurut Goldschmidt (2020) jika masyarakat tidak bekerja, maka mereka tidak akan mendapatkan penghasilan dan jika mereka juga tidak mendapatkan penghasilan, maka mereka tidak dapat memenuhi kebutuhan sehari- hari mereka selama di rumah. Sehingga jika dibiarkan lama-lama akan sangat mengganggu keseimbangan ekonomi masyarakat. Namun mengatasi hal ini, pemerintah melalui kebijakan Work From Home (WFH) diharapkan untuk bisa membuat masyarakat lebih mudah untuk terus bekerja bahkan di tengah-tengah pandemi virus yang mengharuskan mereka tetap bekerja, dengan kebijakan ini masyarakat menganggap bahwa bekerja di rumah akan sangat memudahkan mereka, tetapi ini tidak dapat di pisahkan dari pekerjaan sistem yang semakin sulit.

Menurut Purwanto,dkk. (2020) dalam Work From Home memiliki kelebihan dan kekurangan bagi guru, Work From Home dapat dilakukan secara efektif jika guru dan sekolah melaluinya dengan bertanggung jawab, kedua belah pihak harus lebih memahami tentang kondisi yang terjadi, sambil memberikan kinerja terbaik yang mungkin., meskipun mereka bekerja di tempat yang berbeda. Dalam implementasi pembelajaran secara daring ini paling banyak dilaksanakan dengan menggunakan aplikasi WhatsApp. Dengan pertimbangan rata-rata guru dan siswa atau orang tua siswa memiliki aplikasi ini pada gadget masing-masing, dalam aplikasi ini memiliki fitur WhatsApp Group sehingga guru dan siswa dapat saling berdiskusi serta saling berbagi dokumen. Dalam hal ini guru memanfaatkan fitur ini untuk membagi dokumen materi pembelajaran dan tugas bagi siswa, kemudian siswa akan mengirimkan tugas yang telah mereka selesaikan melalui grup ini pula. Hal yang perlu diperhatikan adalah pemberian tugas disertai pemantauan dan pendampingan oleh guru. Langkah yang dilakukan adalah guru meminta bantuan orang tua maupun kakak siswa sebagai penghubung dengan pemberitahuan lebih dulu melalui WhatsApp Group. Selain itu, perlu disertakan pula koordinasi dan interaksi antara guru dan orang tua siswa berupa video call maupun foto dokumentasi kegiatan belajar siswa di rumah sebagai bentuk laporan bahwa siswa benarbenar melaksanakan pembelajaran di rumah Setyorini (2020).

Menurut Purwanto,dkk (2020) mengungkapkan beberapa tantangan dan kendala yang dialami oleh siswa, guru, dan orang tua dalam pembelajaran online. Dengan demikian tantangan yang terkait dengan siswa adalah komunikasi dan sosialisasi yang 
Jurnal Pendidikan Guru Sekolah Dasar terbatas di antara siswa, tantangan yang lebih tinggi bagi siswa dengan kebutuhan pendidikan khusus, dan waktu penyaringan yang lebih lama. Dalam hal ini orang tua melihat masalah itu lebih terkait dengan kurangnya disiplin belajar di rumah, lebih banyak waktu yang dihabiskanuntuk membantu belajar anak-anak mereka di rumah, terutama untuk anak-anak di bawah kelas 4 di sekolah dasar, kurangnya keterampilan teknologi, dan tagihan internet yang lebih tinggi.

Guru mengidentifikasi lebih banyak tantangan dan kendala, termasuk beberapa pembatasan dalam pilihan metode pengajaran yang biasanya berlaku di kelas tatap muka reguler, cakupan materi kurikulum yang lebih sedikit, kurangnya keterampilan teknologi yang menghambat potensi pembelajaran online, kurangnya kemampuan berbagai sumber dalam bahasa Indonesia yang menghasilkan lebih banyak waktu yang dibutuhkan untuk pengembangan dalam pembelajaran, waktu layar yang lebih lama sebagai hasil dari pembuatan pembelajaran dan memberikan umpan balik pada pekerjaan sis wa, komunikasi yang lebih intens dan juga memakan waktu dengan orang tua, tantangan untuk koordinasi yang lebih baik dengan guru, kepala sekolah, dan tagihan biaya internet yang lebih tinggi. Menurut Rohmadani (2020) kelas online dalam waktu COVID menghabiskan banyak biaya. Ada beberapa hal yang harus dipertimbangkan untuk pengajaran yang lebih baik dalam proses pembelajaran kelas online. Dunia pendidikan menjadi berubah dalam proses pembelajaran dan pada aspek yang lain di sebabkan pandemi COVID19 ini, Sistem pembelajaran dilaksanakan melalui perangkat personal computer (PC) atau laptop yang terhubung dengan jaringan internet. Pendidikan dapat melakukan pembelajaran bersama di waktu yang sama menggunakan grub media sosial seperti WhatsApp (WA), telegram, instagram, aplikasi zoom ataupun media lainnya sebagai media pembelajaran. Dengan demikian, pendidik dapat memastikan peserta didik mengikuti pembelajaran dalam waktu bersamaan, meskipun di tempat yang berbeda. Pendidik pun dapat memberi tugas terukur dengan tujuan materi yang disampaikan kepada peserta didik. Tapi, kasus yang banyak terjadi ketika penerapan sistem pembelajaran online ini di antaranya, tidak meratanya siswa dan orang tua siswa yang pandai mengoperasikan media online, tidak semua orang tua siswa mampu membeli kouta internet, sinyal internet di rumah siswa tidak terjangkau, sebagai besar orang tua siswa yang kondisinya ekonominya pas-pasan, juga tidak memiliki ponsel pintar atau smartphone sebagai sarana belajar secara online untuk anak mereka dan kurang terkontrol disebabkan tidak langsung tatap muka.

\section{KESIMPULAN}

Berdasarkan analisis terhadap konten dari kurikulum 2013 yang terdiri dari standar kompetesi lulusan, standar isi, standar proses, kompetensi dasar, standar penilaian, Permendikbud No 36 tahun 2013 dan Permendikbud no 160 tahun 2014 yang menjadi dasar penerapan kurikulum $2013 \mathrm{di}$ Indonesia dapat disimpulkan bahwa kurikulum 2013 adalah kurikulum yang telah dibuat dengan perencanaan yang matang dan masih relevan menghadapi tantangan zaman dan sesuai dengan kebutuhan perkembangan peserta didik. Dikarenakan sekarang masih dalam masa pandemi COVID-19 maka dalam pendidikan kurikulum 2013 diterapkan sesederhana mungkin agar pendidikan di Indonesia masih bisa terlaksana.

Dalam penelitian ini terdapat beberapa dampak yang dialami oleh peserta didik, guru, serta orang tua dalam kegiatan belajar mengajar online seperti penguasaan teknologi masih kurang, adanya penambahan biaya kuota internet, adanya pekerjaan tambahan untuk orang tua dalam mendampingi anakanaknya belajar, komunikasi dan sosialisasi antar siswa yang menurun, guru dan orang tua 
Jurnal Pendidikan Guru Sekolah Dasar menjadi berkurang interaksinya dan jam kerja yang menjadi tidak terbatas bagi guru karena harus berkomunikasi dan berkoordinasi dengan orangtua, guru lain, dan kepala sekolah setiap waktu. Disaat masa pandemi COVID-19 mempengaruhi banyak hal termasuk kehidupan pendidikan, orang tua peserta didik, peserta didik dan proses pembelajaran.

Sebagai orang guru yang memiliki tanggung jawab untuk mendidik para siswa tidak dapat berhenti. Berdasarkan hasil review dan pembahasan, dapat disimpulkan bahwa sistem pembelajaran daring dengan memanfaatkan platform digital pada jenjang sekolah dasar dan menengah cenderung mengubah wajah pendidikan ke arah yang lebih baik, lebih efektif, dan lebih menyenangkan, tetapi ada dampak positif dan negatif nya juga, disini guru pun menjadi semakin inovatif dalam mengemas bahan ajar dan semakin kreatif mengembangkan metode pembelajaran untuk menarik antusiasme siswa dari dampak positifnya. Dampak negatif nya antara siswa dan orang tua siswa yang pandai mengoperasikan media online, tidak semua orang tua siswa mampu membeli kouta internet, sinyal internet di rumah siswa tidak terjangkau karna di wilayah pemukiman jauh dari perkotaan, sebagai besar orang tua siswa yang kondisinya ekonominya pas-pasan, juga tidak memiliki ponsel pintar atau smartphone sebagai sarana belajar online. Walaupun demikian perlu dilakukan penyesuaian kembali dengan beragam kemampuan masing- masing guru, siswa, dan orang tua siswa dalam memberikan fasilitas pembelajaran daring ini, sehingga kendala yang dialami dapat diminimalisir.

\section{DAFTAR PUSTAKA}

Abbas, E. W., \& Erlyani, N. (2020). Menulis di Kala Badai Covid-19.

Abbas, E. W., \& Erlyani, N. (2015). Pendekatan Saintifik Dalam ImplementasiKurikulun 2013.
Bacow, L. (2020). COVID-19 - Moving classes online, other updates. [Community Message].Harvard University.https://www.harvard.edu/cov id-19- moving- classes- onlineotherupdates

Daryanto. (20/4). Pendekatan pembelajaran saintifik Kurikulum20I3. Yogyakarta:Gava Media.

Desri Arwen. (2020). Student Learning Motivation Influences The Development Of The Corona Virus Pandemic (COVID 19). International Journal of Advanced Scienceand Technology.

Drell, P. (2020, March 6). COVID-19 update from Provost Persis Drell.[Community Update].Stanford University.

Fadlillah, M. (20|4). Implementasi Kurikulum 2013 dalam pembelajaran SD/MI, SMP/MTS, dan SMA/MA. Yogyakarta: Ar-Ruzz Media.

Fernandes, R. (20/9). Relevansi Kurikulum 2013 dengan kebutuhan Peserta didik diEra Revolusi 4.0. SOCIUS, 6(2), 7080.

Goldschmidt, K. (2020). The COVID-19 Pandemic: Technology Use to Support the Wellbeing of Children. Journalof Pediatric Nursing.

Keyes, G. (2010). Teaching the scientific method in the social sciences. The JournalofEffective Teaching, 10(2), 1828. Retrieved from http://www.uncw.edu/jet/articles/Voll 0 2/Volume 1002.

Kunandar. (20/3). Penilaian autentik:penilaian hasil belajar peserta didik berdasarkan Kurikulum 2013. Jakarta: Rajawali Pers.

Kurniawan, G. F. (2020). Problematika Pembelajaran Sejarah dengan SistemDaring. Diakronika, 20(2), 76-87.

Kusumadewi, R. F., Yustiana, S., \& Nasihah, K. (2020). Menumbuhkan KemandirianSiswa Selama Pembelajaran Daring Sebagai Dampak Covid-19 Di Sd. Jurnal Riset Pendidikan Dasar (JRPD), I (I).

Lee, A. (2020). Wuhan Novel Coronavirus (COVID-19): Why Global Control is Challenging?. Public Health, I79, AIA2. 


\section{TUNAS}

Jurnal Pendidikan Guru Sekolah Dasar

Muyas, M. (2020). Dampak Positif Dan Negatif Metode Belajar Daring Bagi OrangTua. Jurnal TAUJIH, I3(0I).

Purwanto, A., Pramono, R., Asbari, M., Hyun, C. C., Wijayanti, L. M., \& Putr i, R. S. (2020).Studi Eksploratif Dampak Pandemi COVID-19 Terhadap Proses PembelajaranO nline di Sekolah Dasar. EduPsyCouns: Journal of Education, Psychology and Counseling, I- 12.

Riadin Agung, Muhammad Jailani dan Ummi Qudsiyah. 2020. Optimalisasi Kompetensi Dan Kinerja Guru Ekonomi Dalam Pembelajaran Daring Pada Masa Pandemic Covid-19 Berbasis ICT. JMM (Jurnal Masyarakat Mandiri). 4:6(I250-|26I).

Rohmadani, A. I. (2020). Dampak Covid 19 Terhadap Cara Berpikir dalam Pembelajaran Daring: Studi Kasus di Yogyakarta. Edification Journal: Pendidikan Agama Islam, 3(I), I25-I 34.

Setyorini, I. (2020). Pandemi COVID-I9 dan Online Learning: Apakah Berpengaruh Terhadap Proses Pembelajaran Pada Kurikulum 13,Journal of Industrial Engineering\& Management Research, 95- 102. 